\title{
THE OCCURRENCE OF ANTIBACTERIAL SUBSTANCES ACTIVE AGAINST MYCOBACTERIUM TUBERCULOSIS IN SEED PLANTS ${ }^{1}$
}

\author{
By R. Y. GOTTSHALL, E. H. LUCAS, ARDETH LICKFELDT, AND J. M. ROBERTS \\ (From the Division of Laboratories, Michigan Department of Health, Lansing, Michigan, and \\ the Michigan Agricultural Experiment Station, East Lansing, Michigan)
}

For many centuries green plants have been used for the treatment of various diseases. Tuberculosis is no exception, and numerous plants and plant products have, at one time or another, been reported to be of value in the treatment of this disease.

During the past few years a number of investigators have surveyed seed plants for sources of antibacterial activity (1-10). In most of these studies a Gram-positive organism, Staphylococcus aureus or Bacillus subtilis, and a Gram-negative organism, Escherichia coli or Salmonella typhosa, were used for detecting antibacterial properties. In some cases the active materials or purified preparations derived from them were then tested against a variety of microorganisms.

In this exploratory survey a strain of Mycobacterium tuberculosis was used for assay because of the assumption that some plants might contain substances specifically antibacterial for the tubercle bacillus. These would be missed in any assay using other test organisms. To obtain more information on the antibacterial properties of the extracts, however, most of them were also tested for their effect on Staph. aureus and E. coli.

Early in the study it was found that some plants contained substances active against the tubercle bacillus but that all or much of the activity was lost in the presence of whole blood. In subsequent tests the active plant extracts were also assayed in media to which blood had been added.

\section{METHODS}

Crude plant materials were used for the preliminary screening. The plants were either used in a fresh state immediately after collection, or dried and extracted at a later date. Whenever possible the use of entire plants for

1 Presented at the Second National Symposium on Recent Advances in Antibiotics Research held in Washington, D. C., April 11-12, 1949, under the auspices of the Antibiotics Study Section, National Institutes of Health, Public Health Service, Federal Security Agency. preparation of representative extracts was avoided. In most instances, either leaves or stems or roots or, if the plant was in the stage of flowering, inflorescences were extracted separately. Sometimes different organs had to be combined because of insufficient amounts of material.

The plants tested were green plants, the majority belonging to the subdivision Angiospermae. The system of classification used follows the synopsis of the plant kingdom, published in L. H. Bailey's Standard Cyclopedia of Horticulture (11) and based on "Die Natürlichen Pflanzenfamillien" by Engler and Prantl.

The preparation of the plant material to be tested was essentially the one described by Lucas et al. (12). A Waring Blendor was the main tool for the disintegration of the plant parts. However, in the present study extractions with boiling water and with ethanol were made in addition to the customary cold-water extraction. The ethanol extraction followed the technique of the coldwater extraction with the exception that paper was used instead of cheesecloth for the filtration of the macerates. The hot extraction was performed by immersion of the plant materials in boiling water for five to ten minutes, the time depending on the properties of the tissues. All cold-water extracts and any ethanol extracts found to be contaminated were sterilized by passing them through a Seitz filter, boiled preparations by autoclaving.

The extracts were tested for antibacterial properties by making serial dilutions in liquefied glycerol beef extract agar, pH 7.0. The agar was allowed to harden in a slanting position, and after solidification the tubes were inoculated with an 18-to-40-day-old culture of $M$. tuberculosis, strain H37, grown on Petragnani's medium. To prevent evaporation during the long incubation period screw-capped tubes were used for making the cultures. After six weeks of incubation at $37^{\circ} \mathrm{C}$. the cultures were examined. If they were inhibited the highest dilution in which no growth occurred was recorded. The active extracts were then retested on glycerol beef extract agar to which $10 \%$ whole sheep blood had been added.

With the alcoholic extracts allowance had to be made for the inhibitory effect of the alcohol. This solvent was found to inhibit the tubercle bacillus at a dilution of $1: 40$ and therefore only extracts in which there was no growth at a dilution higher than this were considered active.

The antibacterial activity of the extracts against Staph. aureus (F.D.A. strain 209P) and E. coli (SA436) was determined by making serial dilutions in nutrient broth (F.D.A. formula). The broth was inoculated with 1.0 ml. of an 18-to-24-hour broth culture of the organism per $100 \mathrm{ml}$. of medium just before making the dilutions. 
Results were read after incubation for 24 and 48 hours at $37^{\circ} \mathrm{C}$.

It was found that ethanol inhibited both Staph. aureus and $E$. coli at a $1: 8$ dilution. Consequently only extracts showing an inhibition greater than this dilution were recorded as being antibacterial.

\section{RESULTS}

The results of the survey are presented in Table I. They are interesting in many respects. Approximately half the number of species with antibacterial activity against $M$. tuberculosis showed it only against this organism; the others were active also against other organisms. These findings cannot be considered as final since the concentration of the active principles is an unknown factor. It is possible that in some instances materials used merely appeared specific because the antibacterial principle was present in a concentration too low to affect the other or-

TABLE I

Activity of plant extracts against M. tuberculosis, Staph. aureus, and E. Coli

\begin{tabular}{|c|c|c|}
\hline Plant name & Plant part & Result \\
\hline $\begin{array}{l}\text { Juniperus communis } \\
\text { Digitaria sanguinalis } \\
\text { Panicum miliaceum } \\
\text { Phleum pratense } \\
\text { Billbergia pyramidalis } \\
\text { Agave altenuata } \\
\text { Aloe africana } \\
\text { A. arborescens } \\
\text { A. aristata } \\
\text { A. barbadensis } \\
\text { A. Brunnthaleri } \\
\text { A. cameronii } \\
\text { A. candelabrum } \\
\text { A. chinensis } \\
\text { A. commutata } \\
\text { A. distans } \\
\text { A. Eru } \\
\text { A. ferox } \\
\text { A. grandidentata } \\
\text { A. humilis } \\
\text { A. Marlothi } \\
\text { A. microstigma } \\
\text { A. mitriformis } \\
\text { A. nobilis } \\
\text { A. plicatilis } \\
\text { A. robusta } \\
\text { A. saponaria } \\
\text { A. spinosissima } \\
\text { A. striata } \\
\text { A. succotrina } \\
\text { A. Thorncroftii } \\
\text { A. oariegata } \\
\text { A. virens } \\
\text { A. zebrina } \\
\text { Colchicum autumnale } \\
\text { Gasteraloe pethamensis } \\
\text { Gasteria acinacifolia } \\
\text { G. carinata } \\
\text { G. excelsa } \\
\text { G. maculata } \\
\text { G. obscura } \\
\text { G. picta } \\
\text { Smilaxctata offinalis } \\
\text { S. ornata } \\
\text {. }\end{array}$ & $\begin{array}{l}\text { Fr } \\
\text { E } \\
\text { Fl and L } \\
\text { St and R } \\
\text { E } \\
\text { Fl and L } \\
\text { L } \\
\text { L } \\
\text { L } \\
\text { L } \\
\text { L } \\
\text { L } \\
\text { L } \\
\text { L } \\
\text { L } \\
\text { L } \\
\text { L } \\
\mathbf{L} \\
\mathbf{L} \\
\mathbf{L} \\
\mathbf{L} \\
\mathbf{L} \\
\mathbf{L} \\
\mathbf{L} \\
\mathbf{L} \\
\mathbf{L} \\
\mathbf{L} \\
\mathbf{L} \\
\mathbf{L} \\
\mathbf{L} \\
\mathbf{L} \\
\mathbf{L} \\
\mathbf{L} \\
\mathbf{L} \\
\mathbf{L} \\
\mathbf{R} \\
\mathbf{L} \\
\mathbf{L} \\
\mathbf{L} \\
\mathbf{L} \\
\mathbf{L} \\
\mathbf{L} \\
\mathbf{L} \\
\mathbf{L} \\
\mathbf{R} \\
\mathbf{R} \\
\end{array}$ & 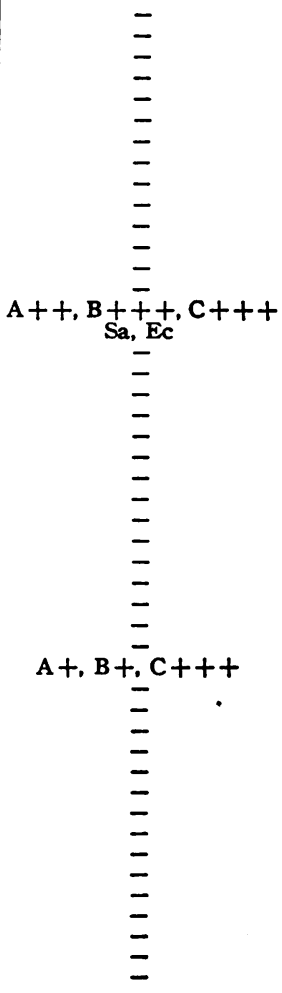 \\
\hline
\end{tabular}

TABLE I-Continued

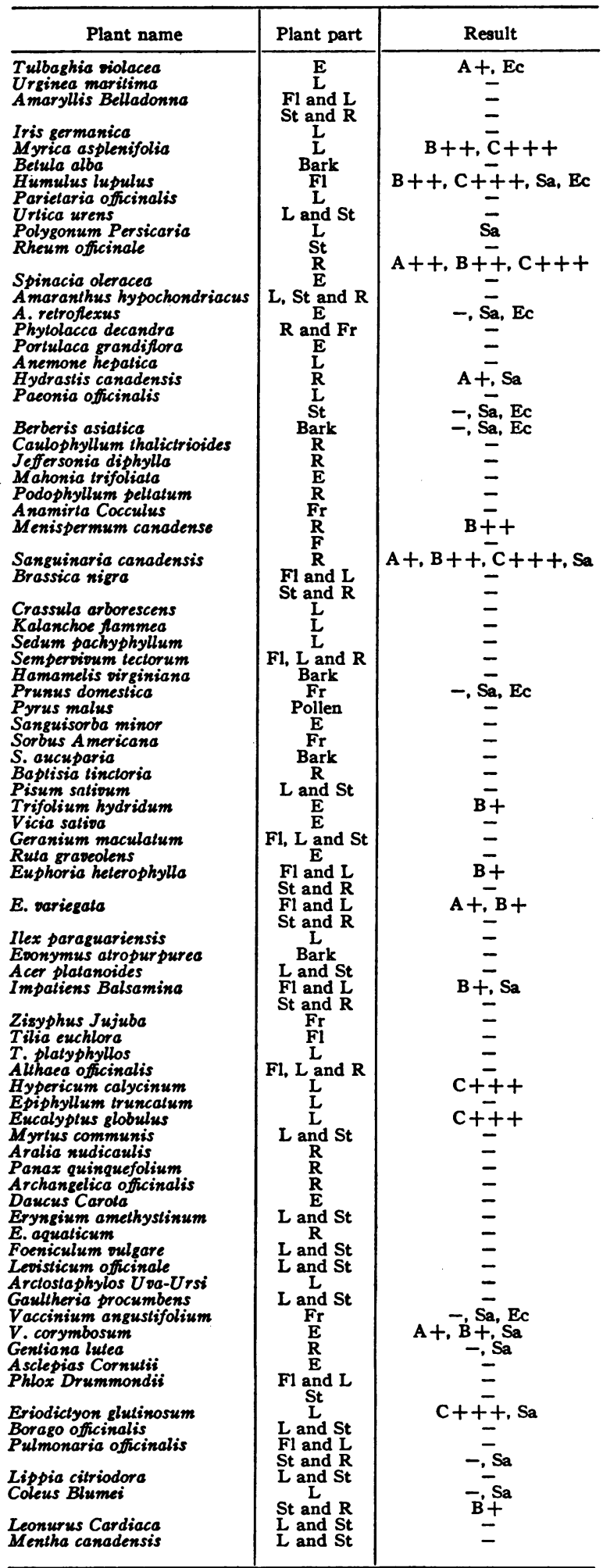


TABLE I-Continued

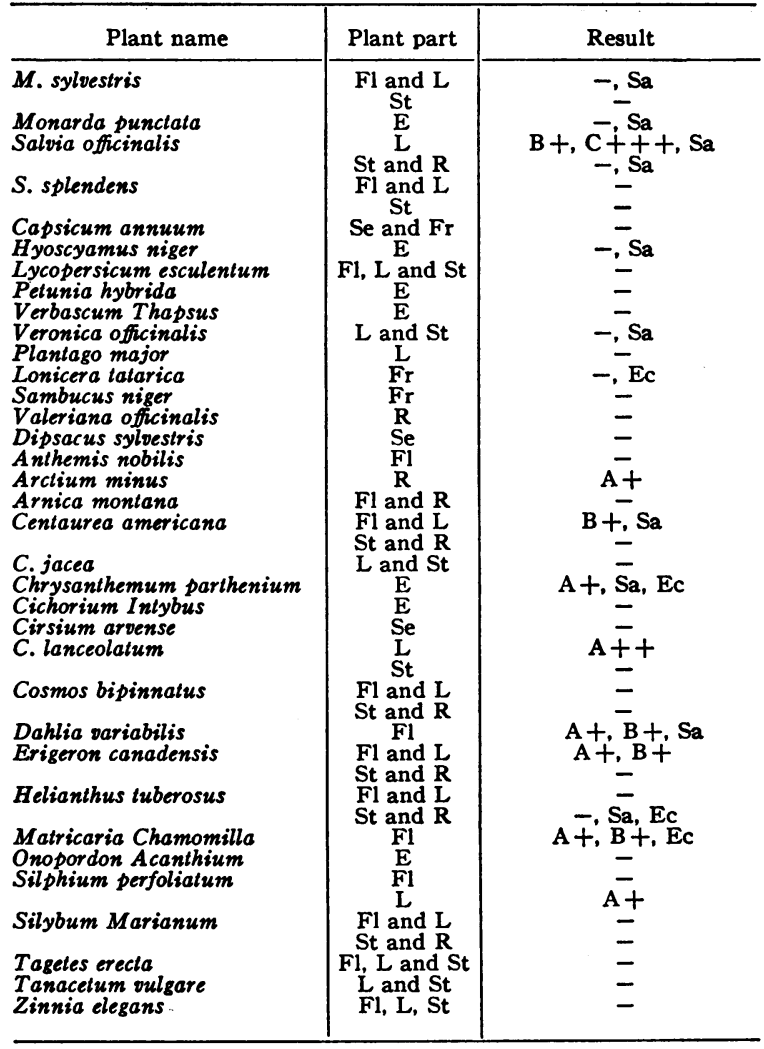

Activity against $M$. tuberculosis is indicated by,+++ or +++ , according to potency of extracts. A, B, or $C$ preceding these signs indicates cold water, boiling water, or ethanol extract respectively. Lack of activity is signified by - . Sa and Ec denote activity against Staph. aureus and $E$. coli.

Plant parts are designated as follows: Entire plant, E; flowers, Fl; leaves, L; stems, St; roots, R; seeds, Se, and fruits Fr.

ganisms. Nevertheless, by testing the plant extracts against the customary organisms only, half of the materials with activity against the tubercle bacillus would have been overlooked.

Some of the extracts antibacterial for $M$. $t u$ berculosis were tested using for assay the rapidly growing acid-fast strain 607. Only three out of 20 extracts were found to be active against this acid-fast strain.

The materials in which activity against the tubercle bacillus was observed were derived from 27 species, which belonged to 16 families. Eight species belonged to the family Compositae, three to Liliaceae, two to Euphorbiaceae, two to Labiatae. Six of the materials with exclusive activity against $M$. tuberculosis were from Compositae and two from Euphorbiaceae.
Plant leaves were carriers of active principles in most cases. Nine of the 27 plants showed activity in the leaf extracts. In five cases it was found in the extract of leaves and flowers combined while flowers alone showed activity only in three cases. In five plants the activity was found in the roots, and four of the extracts prepared from entire plants inhibited growth of the tubercle bacillus. No activity was recorded in seeds and fruits. Stems and roots combined showed activity in one case. This plant, Coleus Blumei, is the only one where extracts of different parts showed specific activities, the leaf extract being active against Staph. aureus, the stems and roots against the tubercle bacillus. There were two other cases, one in the same family, where the apparent specificity might be explained by the greater sensitivity of Staph. aureus to the active principle. However, in both cases the possibility of the presence of more than one antibacterial principle could not be ruled out.

Only one of the 35 antibacterial plant samples did not show a loss of activity in the presence of whole blood. The other extracts lost all or part of their antibacterial properties in contact with it.

This report is the first in a series involving the investigation of seed plants for principles antagonistic to the tubercle bacillus. Testing of crude materials is being continued. Some of the plant materials, which in the exploratory phase inhibited the growth of $M$. tuberculosis, are under further study.

As Kavanagh (13) very aptly expressed it, "compounds active against more than a few common bacteria must be found, if the potentialities of antibiotic substances as specific inhibitors of microorganisms are to be realized fully. This can be done only by using the organism to be inhibited as the test object in the survey."

\section{SUMMARY}

The antibacterial activity against $M$. tuberculosis, strain H37, of 211 plant samples from 161 species belonging to 53 families of seed plants was determined by serial dilution tests. Each sample was extracted separately with cold water, boiling water and ethanol. Twenty-seven species were active, 13 of them specifically against $M$. tuberculosis, while not interfering with the growth of 
Staph. aureus and E. coli. The activity was found in various parts of the plants, mostly in the leaves.

\section{ACKNOWLEDGMENT}

We wish to thank Mrs. J. McCallum and Mrs. R. Engstrom for technical assistance.

\section{BIBLIOGRAPHY}

1. Osborn, E. M., On the occurrence of antibacterial substances in green plants. $\mathrm{Br}$. J. Exper. Path., 1943, 24, 227.

2. Huddleson, I. F., DuFrain, J., Barrons, K. C., and Giefel, M., Antibacterial substances in plants. J. Am. Vet. M. A., 1944, 105, 394.

3. Cavallito, C. J., and Bailey, J. H., Preliminary note on the inactivation of antibiotics. Science, 1944, $100,390$.

4. Lucas, E. H., and Lewis, R. W., Antibacterial substances in organs of higher plants. Science, 1944, $100,597$.
5. Pederson, C. S., and Fisher, P., Bactericidal activity of vegetable juice. J. Bact., 1944, 47, 421.

6. Sanders, D. W., Weatherwax, P., and McClung, L. S., Antibacterial substances from plants collected in Indiana. J. Bact., 1945, 49, 611.

7. Atkinson, N., Antibacterial activity in members of native Australian flora. Nature, 1946, 158, 876.

8. Carlson, H. J., Bissell, H. D., and Mueller, M. G., Antimalarial and antibacterial substances separated from higher plants. J. Bact., 1946, 52, 155.

9. Little, J. E., and Grubaugh, K. K., Antibiotic activity of some crude plant juices. J. Bact., 1946, 52, 587.

10. Carlson, H. J., Douglas, H. G., and Robertson, J., Antibacterial substances separated from plants. J. Bact., 1948, 55, 241.

11. Bailey, L. H., Standard Cyclopedia of Horticulture. The Macmillan Co., New York, 1941.

12. Lucas, E. H., Pearson, K., Lewis, R. W., and Vincent, B., Preparation of crude plant extracts and their assay for presence of antibacterial substances. Food Research, 1948, 13, 82.

13. Kavanagh, F., Advances in Enzymology. Interscience Publishers Inc., New York. 1947, 7, 461. 